\title{
BIOCHEMICAL RESPONSES IN OREOCHROMIS NILOTICUS AFTER EXPOSURE TO SUBLETHAL CONCENTRATIONS OF DIFFERENT POLLUTANTS
}

\author{
Nahed S. Gad
}

National Institute of Oceanography and Fisheries ,Cairo Egypt

Keywords: biochemical responses, O.niloticus, malathion, lannate, phenol, AChE, GST

\begin{abstract}
Zish responses have been used as biomarker of aquatic pollution. The - objective of this study was to determine some biochemical responses in Oreochromis niloticus after exposure to sublethal concentrations of three different pollutants . In the present study ,malathion $(1.75 \mathrm{mg} / \mathrm{L})$, (organophosphorus insecticide ) ,lannate ( $0.65 \mathrm{mg} / \mathrm{L}$ ) (carbamate insecticide) ) and phenol (9 mg/L) (phenolic compound) were selected as model compounds of three different pollutants. Studies were carried out to determine the effect of these compounds in acetylcholinesterase enzyme( AchE) as a biomarker of effect and glutathione S - transferase ( GST) enzyme as a biomarker of defense in brain, serum and liver of $O$. niloticus after three weeks of exposure. The results indicated that : 1-the activity of acetylcholinesterase enzyme decreased significantly in brain ,serum and liver of $O$. niloticus exposed to malathion and lannate after 1, 2 and 3 weeks when compared with the control group, phenol treated group has low effect. 2- the activity of glutathione S- transferase decreased significantly in brain and serum of O. niloticus exposed to malathion and lannate, but in phenol treated group the activity of glutathione $\mathrm{S}$ - transferase increased significantly in brain and serum. 3-the activity of glutathione S- transe ferase increased significantly in liver of O. niloticus exposed to phenol more than malathion and lannate.
\end{abstract}

\section{INTRODUCTION}

As a result of human developmental activities, a number of environmental pollutants such as pesticides, heavy metals and aromatic compounds entered the water courses through air, river discharge and land drainage. The behavior of aquatic organisms largely depends on the 
physical and chemical state in which they are present and the prevailing environmental condition.

In recent years a number of biomarkers have been suggested to environmental biomonitoring programs for assessment of stress caused by pollution , especially in aquatic organisms. These biomarkers include: 1-biomarkers of exposure ( defense), which are only indicative for an exposure to an environmental stress, and 2- biomarkers of effect (defect), which are indicative both for exposure and occurrence of adverse ( e.g toxic) effects on the (bioindicator) organisms studied (Sanders and Martin,1993). The aim of programs based on biomarkers was the establishment of early warning systems allowing the detection of environmental stress before irreversible damage occurs.

The impact of aquatic pollution on human and animal life has become a matter of great concern. Fish responses have been used as biomarkers of aquatic pollution (Berntessen et al., 2003; Ek et al., 2005) .

The responses of various Xenobiotic metabolizing enzymes in fish are rapidly evolving as important biomarkers for monitoring unacceptable levels of environmental contamination .

Organophosphorus and carbamate compounds are very widely used insecticides. They are toxic because they inhibit acetylcholinesterase (AChE), the enzyme that is responsible for hydrolyzing and so deactivating acetylcholine in the nervous system. AChE - inhibiting pesticides can contaminate surface waters through unintentional drift of aerial spraying for agricultural use, through watershed drainage or accidental spillage and even through intentional application ( Ibrahim et al., 1998) .

Phenol is a common toxic component of various industrial waste waters. It has antiseptic properties and is a major intermediate in the manufacturing of dyes, medical products, resins and other industrial compounds ( Assem et al., 1992) . Phenolic compounds can affect fish adversely by direct toxicity to fish and their consumers by lowering the amount of available oxygen by tainting the fish flesh and on enzyme system by uncoupling oxidative phosphorylation and tissues damage (Mohamed et al ., 1997) .

In Egypt, effluent of oil refiners contains phenol and the receiving waters are subjected to low level chronic phenol pollution .

Xenobiotic metabolism in fish is often referred to a biotransformation reaction or detoxification reaction and the pathway involved is usually divided into phase I and phase II reactions. In phase I 
reaction a function group of xenobiotic oxidized or hydrolyzed by mixed function oxidase system ( MFO) is involved in oxidation by a variety of isozymes of cytochrome P450. Phase II reaction biosynthetic reaction in phase I derived metabolite is covalently linked to endogenous molecules such as glutathione, which is catalyzed by glutathione $\mathrm{S}$ transferase enzymes.

Phase II enzymes were measured by catalytic activity of glutathione $-\mathrm{S}$ transferase ( GST) (Behrens and Segner , 2001) .

Inhibition of acetylcholinesterase activities ( neurotoxicity) and induction of glutathione -S- transferase activities ( antioxidant defense ) in fish are used as indicator of environmental pollution. So the aim of this study was to evaluate brain , serum and liver acetylcholinesterase activities as a biomarker of the effect and glutathione $-\mathrm{S}$ transferase activities as a biomarker of defense in Oreochromis niloticus after exposure to sublethal concentrations of malathion, lannate and phenol for a period of three weeks

\section{MATERIALS AND METHODS}

\section{Pollutants}

1- Malathion: is an organophosphorus insecticide manufactured by ElNasr pharmaceutical chemicals company as a stock solution (57\%) with M. Wt of 330 .

2- Lannate : It is an carbamate insecticide with M. Wt. of 160 and available in 9o \% powder and soluble in water manufactured by Dupont Co.

3- Phenol : Technical grade of phenol $\mathrm{C} 6 \mathrm{H} 5 \mathrm{OH}, \mathrm{M}$. wt. 94.11 manufactured by El.Nasr pharmaceutical chemical company

\section{Experimental animals}

Healthy living specimens of Oreochromis niloticus were collected from a fish farm at EL Kanater -AL Khairya. Fish were examined for any pathological symptoms. They were transported to the laboratory conditions for a period of 15 days for acclimation in well aerated dechlorinated tap water. The water in each aquarium was continuously aerated by an air compressor. They were transferred to experimental glass aquaria each of $100 \mathrm{~L}$.Water temperature was recorded daily and water analyses were carried out each week to determine $\mathrm{pH}$, dissolved oxygen , ammonia, nitrate and nitrite according to APHA ( 1992). Fish were fed on artificial pellets of $30 \%$ protein once per day . 


\section{Experimental design}

Experiments were carried out on Oreochromis niloticus weighing $70 \pm 12.0 \mathrm{~g}$ with total length $17.3 \pm 2.0 \mathrm{~cm}$.

Based on the results of Mohamed et al. ( 1997 ) Gad ,( 1999 )the sublethal concentrations ( 1/4 LC50) of malathion, lannate and phenol were $1.75,0.65$ and $9 \mathrm{mg} / \mathrm{L}$ respectively.

In the present experiment fish were divided into four groups, in three replicates each group was 24 fish as follows :

Group I : Exposed to $1.75 \mathrm{mg} / \mathrm{L}$ of malathion .

Group II : Exposed to $0.65 \mathrm{mg} / \mathrm{L}$ lannate .

Group III : Exposed to $9 \mathrm{mg} / \mathrm{L}$ phenol .

Group IV: Served as control.

The water in each aquarium was renewed every four days during the experimental period ( three weeks ) and freshly prepared solution was added to bring the concentrations of the pollutant to the requisite levels . Six fish from each of the four groups were taken out for dissection on $1^{\text {st }} ., 2^{\text {nd }}$ and 3 weeks of exposure.

Blood samples were taken by severance of the caudal peduncle of fish and collected in small vials, left to clot and then centrifuged at 3000 r. p. $\mathrm{m}$ for 10 minute to obtain serum for enzyme determination.

Brains and livers tissues were isolated immediately. The tissues were homogenated in cold $0.15 \mathrm{M} \mathrm{Kcl}$ solution using homogenizer. Tissue homogenates were centrifuged at 15, $000 \mathrm{r}$.p .m for $10 \mathrm{~min}$ and used for the enzyme assays .

The activities of acetylcholinesterase was measured using commercial kit produced by Bohringer Mannhim based on Ellmann et al . ( 1961) and the activities of glutathione $-\mathrm{S}$-transferase was measured using Vassey and Boyer ( 1984). The enzymes activities were expressed as $\mathrm{U} \mathrm{mol} / \mathrm{min} / \mathrm{mg}$ protein .

\section{Statistical analysis}

The significance between control and experimental results was analyzed statistically by using the Student's t - test ( Snedecor , 1962 ) .

\section{RESULT}

The activity of acetylcholinesterase was measured after 1,2 ,and 3 weeks of exposure to malathion, lannate and phenol . The results are reported in Table (2).

Table (2) shows that the activities of AChE in brain , serum and liver of $O$. niloticus exposed to malathion and lannate were decreased 
significantly after 1,2 and 3 weeks of exposure $(\mathrm{P}<0.01)$ when compared with the control group. However, in phenol treated groups the activities of AChE were not significantly changed.

In general, most polluted fish had inhibited acetylcholinesterase activities when compared with the control group and the greatest inhibition was observed in malathion and lannate exposed fish and significant inhibition in phenol exposed fish after 3 weeks.

Table ( 3 ) reveals that the activity of glutathione - S transferase in brain and serum of $O$. niloticus was significantly decreased $(0.44+$ $0.12,0.49 \pm 0.01$ and $0.047 \pm 0.002,0.050 \pm 0.002 \mathrm{U}$ mol / min / $\mathrm{mg}$ protein ) in malathin and lannate exposed fish after 3 weeks of exposure as compared with the control group ( $0.60 \pm 0.13$ and $0.061+0.0001)$ ,while the activity increased in phenol exposed fish ( $0.72 \pm 0.01$ and $0.076 \pm 0.001 \mathrm{U} \mathrm{mol} / \mathrm{min} \mathrm{mg}$ protein.). However, the activity of glutathione $-\mathrm{S}$ transferase in liver was increased significantly in malathion, lannate and phenol exposed fish after 3 weeks of exposure with induction of $13.0 \%, 51.5 \%$ and $102 \%$ and specific activities of $1.12 \pm 0.08,1.5 \pm 0.23$ and $2.0 \pm 0.35 \mathrm{U} \mathrm{mol} / \mathrm{min} / \mathrm{mg}$ protein respectively .

\section{DISCUSSION}

The pharmacological effect of organophosphorus and carbamate insecticides is one of the main causes of disruption of nerve impulse transmission in the central and peripheral nervous system by inhibition of acetylcholinesterase ( Daabees et al., 1992).

Inhibition of this enzyme lead to building up of acetylcholine at sites of cholinergic synapses and hence to permanent nerve stimulation with extreme lethal results .

Results of the present study showed that inhibition of AChE activities in brain, serum and liver significantly increased in malathion poisoned fish ( $75,39.8$ and $55.9 \%$ ) and least in lannate and phenol ( $62.5,40.5,30.2 \%$ and $25,24.5,23.3 \%$ ) after1, 2 and 3 weeks of exposure respectively .

The significant inhibition of acetylcholinesterase by malathion (organophosphorus) and lannate (carbamate) may be due to phosphorelation or carbamilation of esterase site, serine hydroxyl group of the enzyme .Thus, the anticholinesterase potency depends largely on the phosphorylating or carbamylating ability of either organophosphate or carbamate ester respectively . 
The inhibition of AChE activities in brain, serum and liver of $O$. niloticus in the present investigation is in accordance with that recorded in the brain of Zebrafish exposed to $0.5-1.1 \mathrm{ppm}$ malathion for 7 days ( Ansari and Kumar, 1984 ), in brain of Cyprinus carpio exposed to dimethoate ( Satyadevan et al., 1993 ), in brain of $O$.niloticus exposed to malathion and bayluscide for 30 days ( Danasoury et al., 1997) and in brain and muscle of Chinook salamon exposed to chloropyrifos for $96 \mathrm{hr}$. ( Wheelock et al .,2005) ).

Since organophosphorus and carbamates have a relatively short half life, the assessment of cholinesterase inhibition is a useful tool to evaluate their environmental impact on aquatic biota, even when they are no longer detectable in the environment ( Valbonesi et al., 2003 ). The inhibition of neural acetylcholinesterase by organophosphorus and carbamate pesticides is the primary toxic mechanisms of these compounds .

In Mammals , glutathione - S - transferase are thought to play a physiological role in the inhibiting the detoxification of potential alkylating agents including drugs, pesticides and other non polar environmental agents. These enzymes catalyze the reactions of such compounds with the $\mathrm{SH}$ group of glutathione ( $\mathrm{GSH}$ ), there by neutralyasing their electrophilic sites and rendering the products to more water soluble .Glutathione conjugates are through to be metabolized further by cleavage of the glutathione and glycine residues (Daabees et al .,1992).

The present results revealed inhibition of brain and serum glutathione -S transferase activities of $O$.niloticus by malathion and lannate compared with the control group after 3 weeks of exposure, while induction of glutathione- $\mathrm{S}$ transferase in brain, serum and liver were recorded in phenol treated fish after three weeks of exposure. The induction of glutathione S- transferase in liver, brain and serum of $O$. niloticus exposed to phenol to protect biological macro molecule from potential toxicity of phenol and its metabolites .

The increased glutathione -S transferase activities indicate that phenolic compound oxidized macromolecule and activates antioxidant defense system, which may be useful as general biomarkers of phenolic compounds exposure .

Induction of glutathione $-S$ transferase activities in liver of $O$. niloticus exposed to phenol is greater in brain and serum . The inhibition of glutathione-S transeferase activities in brain and serum of 
O. niloticus exposed to malathion and lannate may be due to reduction of enzymes ability to protect the fish from certain electrophilic toxins which are metabolized by the transferase .

Induction of glutathione $-\mathrm{S}$ transferase activities in brain serum and liver of $O$. niloticus exposed to phenol in the present investigation is in accordance with that recorded in brain , serum and liver of Clarias lazera exposed to synthetic pesticides (Daabees et al., 1992), in liver and kidney of $O$. niloticus captured from sewage polluted sites ( Hamed et al ., 2003 ), in liver of Rainbow trout exposed to cadmium ( Ait -aissa et al., 2003), in liver of Cyprinus carpio exposed to polychlorinated biphenyles ( Schmidt et al., 2004 ) and in liver of rainbow trout (Oncorhynchus mykiss ) injected by 100,200 and $400 \mathrm{mg} / \mathrm{kg}$ body weight trinitrotoluene for $72 \mathrm{hr}$ ( Ek et al., 2005).

In conclusion, the results revealed that inhibition of acetylcholinesterase activities in brain serum and liver of fish used as useful indicator of aquatic pollution by organophosphorus and carbamate insecticides ( biomarker of effect ), Moreover induction of glutathione $-\mathrm{S}$ - transferase enzyme in fish used as an indicator of aquatic pollution by phenolic compounds ( biomarker of defense ) .

\section{REFERENCES}

Ait - aissa, S.; Ausseil, O.; Vindimian, E.; Garnier Iaplace, J. and Porcher J. M. (2003). Biomarker responses in Juvenile rainbow trout ( Oncorhynchus mykiss )after single and combined exposure to low doses of cadmium ,zinc PCB 77 and 17 Oestradiol . Biomarkers, 8 ( 6) :491 - 508.

Ansari, B. A. and Kumar , K . (1984). Malathion toxicity in vivo inhibition of acetylcholinesterase in the Branchydonio rerio . Toxicol., 20: 283- 287 .

APHA ( American Public Health Association ) (1992). Standard methods for examination of water and wastewater $: 18^{\text {th }}$ ed., Greenberg, A. E.; Clesceri ,L. S . and Eaton, A. D . ( editors) APHA , WEF \& AWWA ,Washington D. C . 
Assem, H.; Abo Hegab, S. and Belal , I .(1992) . Comparison of haematological effects of some toxicants on Clarias gariepinus. J . Egypt. Ger . Zol .,9 (A) : 33- 50 .

Behrens, A. and Segner, H. ( 2001). Hepatic biotransformation enzymes of fish exposed to non point source pollution in small streams. J . Aquatic .Eco, Stress and Recovery ,8 ( 3 ): 281-297 .

Berntessen , M . H . ; Atland, A. and Handy, R. D. (2003). Chronic dietary mercury exposure causes oxidative stress, brain lesions and altered behavior in Atlantic salmon ( Salmosalar ) Parr. Aquatic, Toxicol., 65 (1) : 55- 72 .

Daabees, A. Y.; El. Domiatty, N. A.; Soliman , S. A. and El-Toweissy, M. Y. (1992). Comparative action of three synthetic pesticides on serum liver and brain enzymes of the freshwater Clarias lazera , J. Egypt. Ger. Soc. Zool., 10 (A) : 105 -119.

Danasoury, M . A . ; Reda, L . A. ; Shoukry , A. and Fayomy, F .( 1997). Biochemical target effected by two pollutants , J. Egypt. Ger. Sco. Zool., 22 (A) : 33- 54 .

Ek, H.; Dave, G. ; Sturve, J.; Carney, B.; Stephensen , E. and Birgersson, G. (2005). Tenative biomarkers for 2, 4, 6 - trinitrotoluene ( TNT) in fish Oncorhynchus mykiss. Aquatic. Toxicol., $72: 221-230$.

Ellmann ,G. L. ; Courteney, K. D. ; Andres , V. and Featherstone, R. M. (1961). A new and rapid colorimetric determination of acetylcholinesterase activity . Bioch. Pharmac.,1 : 88pp .

Hamed, R . A. ; Farid , N . M . ; Elowa, Sh . E . and Abdolla , A . M . ( 2003) .Glutathione related enzyme levels of freshwater fish as bio-indicator of pollution. The Environmentalist, 23 ( 4 ) :3 13-322

Ibrahim , H. ; Kheir , R. ; Helmi, S. ; Lewis , J. and Crane , M. (1998). Effects of organophosphorus ,carbamate ,pyrethroid and organochlorine pesticides and heavy metals on survival and 
cholinesterase activity of Chironomus riparius Meigen. Bull. .Environ. Contam.Toxicol.,60: 448 - 455 .

Gad , N. S. (1999). Bioassay studies for assessment of the effect of some pesticides on Tilapia zillii living in fresh and saline water .Ph .D . Thesis, Fac. Sci. Ain Shams. Univ. 251pp.

Mohamed , A. ; Abass, S. A. and Fatma, A . S . M . ( 1997) . Toxicological and pathological effects of phenol on Oreochromis niloticus and Tilapia zillii. Egypt. J. Zool., 29: 295 - 319.

Sanders , B. M. and Martin, L. S. ( 1993 ) .Stress protein as biomarkers of contaminant exposure in archived environmental samples. The Science of the total Environment, 139 ( 1400 ) : 459 - 470.

Satyadevan, S.; Kumar, S. and Tembhre, M. (1993) .Acetylcholinesterase activity and enzymes kinetics in the brain of common carp Cyprinus carpio subjected to sub-lethal exposure to dimethioate ,Biotechno. \& Biochem., 57( 9) :1566 - 1577.

Schmidt, K .; Steinberg, C. E .W. ; Fugmader, S . and George ,B O . ( 2004). Xenobiotic substances such as PCB mixtures and TBT can influence swimming behavior and biotransformation activity( GST) of carp Cyprinus carpio). Environ. Toxicol.,19 ( 5) : 460 470.

Snedecor , G. W. (1962). Statistical methods $5^{\text {th }}$ Ed. The Iowa university press .Ames, Iowa, U.S. A.

Valbonesi , P. ; Sartor, G. and Fabbri , E .(2003) .Characterization of activity in three bivalves inhabiting the North Adriatic sea and their possible use as sentinel organisms for bio surveillance programs . The science of total Environment, 312 : 79 -88 . 
Vassey , D . A . and Boyer, T. D. ( 1984) Differential activation and inhibition of different forms of rat liver glutathione $\mathrm{S}$ - transferase by herbicides 2,4 dichlorophenoxyacetate and 2,4,5 trichlorophenoxyacetate ( 2,4 ,5-T ) Toxicol. Appl. Pharm , 73 : 492 - 501

Wheelock, C. E. ; Eder ,K . J . ; Werner ,I .; Huanyg , H . ; Jones ,P . D . and Brammell, B .F . ( 2005) . Individual variability in esterase activity andCY T IA levels in Chinook salmon Oncorhynchus tshawytscha exposed to esfenvalerate and chloropyrifos . Aquatic, Toxicol. ,74: 172-192. 
Table (1): Physical and chemical characteristics of the used dechlorinated tap water

\begin{tabular}{|l|l|}
\hline \multicolumn{1}{|c|}{ Characteristic } & \multicolumn{1}{|c|}{ Values } \\
& \\
\hline Temperature ( C ) & $24.0 \pm 2.00$ \\
pH & $7.8 \pm 0.03$ \\
Dissolved oxygen & $7.1 \pm 0.50$ \\
Total alkalinity & $170.000 \pm 21.000$ \\
No2 & $0.12 \pm 0.004$ \\
No3 & $0.00 \pm 0.001$ \\
NH3 & $0.8709 \pm 0.03$ \\
Conductivity (U mhos/Cm) & $370.00 \pm 10.00$ \\
\hline
\end{tabular}

Values except $\mathrm{pH}$, temperature and conductivity, are expressed in $\mathrm{mg} / \mathrm{L}$ Values are mean + standard deviation

Table (2) : Brain, serum and liver acetylcholinesterase activities of Oreochrmis niloticus exposed to malathion ( $1.75 \mathrm{mg} / \mathrm{L}$ ) ,Lannate ( $0.65 \mathrm{mg} / \mathrm{L}$ ) or phenol ( $9 \mathrm{mg} / \mathrm{L}$ ) for three weeks .

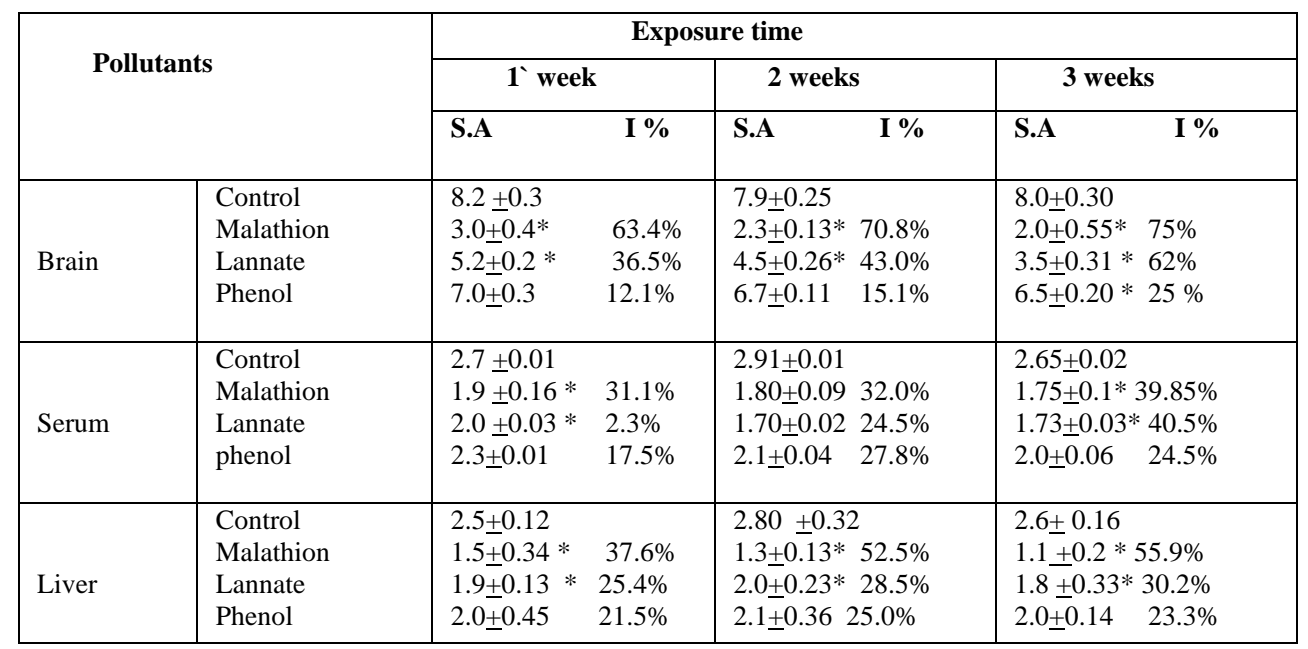

S. A : Specific activity expressed as $\mathrm{U} \mathrm{mol} / \mathrm{min} / \mathrm{mg}$ protein . I \%:Percent of inhibition.

Results are expressed as mean \pm standard error (S.E ) of 6 fishes * Significant at $\mathrm{p}<0.05$. 
Table ( 3) : Brain , serum and liver glutathione $\mathrm{S}$ - transferase activities of $O$. niloticus exposed to malathion ( $1.75 \mathrm{mg} / \mathrm{L})$, lannate ( $0.65 \mathrm{mg} / \mathrm{L})$ and phenol (9 mg/L) for three weeks .

\begin{tabular}{|c|c|c|c|c|c|c|c|}
\hline \multirow{2}{*}{\multicolumn{2}{|c|}{ Pollutants }} & \multicolumn{6}{|c|}{ Exposure time } \\
\hline & & \multicolumn{2}{|l|}{1 week } & \multicolumn{2}{|l|}{2 weeks } & \multicolumn{2}{|l|}{3 weeks } \\
\hline & & S.A & I \% & S.A & I \% & S.A & I \% \\
\hline Brain & $\begin{array}{l}\text { Control } \\
\text { Malathion } \\
\text { Lannate } \\
\text { Phenol }\end{array}$ & $\begin{array}{l}0.63 \pm 0.22 \\
0.58+0.01 \\
0.59+0.02 \\
0.73+0.42 *\end{array}$ & $\begin{array}{l}7.9 \% \\
6.3 \% \\
15.8 \%\end{array}$ & $\begin{array}{l}0.65 \pm 0.12 \\
0.50+0.03 \\
0.55+0.01 \\
0.68 \pm 0.34\end{array}$ & $\begin{array}{c}23.0 \% \\
15.3 \% \\
4.61 \%\end{array}$ & $\begin{array}{l}0.60 \pm 0.13 \\
0.44 \pm 0.12 \\
0.49 \pm 0.01 \\
0.72+0.01^{*}\end{array}$ & $\begin{array}{c}20.6 \% \\
18.3 \% \\
20.0 \%\end{array}$ \\
\hline Serum & $\begin{array}{l}\text { Control } \\
\text { Malathion } \\
\text { Lannate } \\
\text { phenol }\end{array}$ & $\begin{array}{l}0.062 \pm 0.001 \\
0.053 \pm 0.003 \\
0.059 \pm 0.002 \\
0.071 \pm 0.01 *\end{array}$ & $\begin{array}{c}14.5 \% \\
4.3 \% \\
14.5 \% \\
\end{array}$ & $\begin{array}{l}0.059+0.01 \\
0.061 \pm 0.01 \\
0.056 \pm 0.01 \\
0.063+0.02 *\end{array}$ & $\begin{array}{l}3.3 \% \\
5.0 \% \\
6.77 \% \\
\end{array}$ & $\begin{array}{l}0.061 \pm 0.001 \\
0.047 \pm 0.002 \\
0.050 \pm 0.002 \\
0.076 \pm 0.001 *\end{array}$ & $\begin{array}{l}22.9 \% \\
18.0 \% \\
24.5 \% \\
\end{array}$ \\
\hline Liver & $\begin{array}{l}\text { Control } \\
\text { Malathion } \\
\text { Lannate } \\
\text { Phenol }\end{array}$ & $\begin{array}{l}0.9 \pm 0.01 \\
1.1+0.80 * \\
1.0+0.12 * \\
1.6+0.23 *\end{array}$ & $\begin{array}{c}15 \% \\
8 . \% \\
73 . \%\end{array}$ & $\begin{array}{l}0.9+0.01 \\
1.1+0.09 \\
1.4+0.13 * \\
1.8+0.13^{*}\end{array}$ & $\begin{array}{l}20.4 \% \\
42.8 \% \\
83.6 \%\end{array}$ & $\begin{array}{l}0.99 \pm 0.01 \\
1.12 \pm 0.08 * \\
1.5 \pm 0.23 * \\
2.0 \pm 0.35 *\end{array}$ & $\begin{array}{l}13 \% \\
51 \% \\
100 \%\end{array}$ \\
\hline
\end{tabular}

S.A : Specific activity expressed as $\mathrm{U} \mathrm{mol} / \mathrm{min} / \mathrm{mg}$ protein.

I\% :Percent of inhibition or induction.

Results are expressed as mean \pm standard error (S.E ) of 6 fishes.

* Significant at $\mathrm{P}<0.05$ 